\title{
Az in-store marketing innovációinak szerepe a vásárlói élmény megteremtésében és kapcsolódása a digitális térhez
}

\author{
Kontor Enikő - Kiss Marietta - Fehér András \\ Debreceni Egyetem
}

\begin{abstract}
A TANULMÁNY CÉLJA
A tanulmány azokat az innovációkat, tendenciákat tekinti át, melyek meghatározzák napjaink és a közeljövő in-store marketingjének lehetőségeit, kihívásait és egyidejüleg a vásárlói élmény megteremtésében is fontos szerepet játszanak. Kiemelten foglalkozunk azzal a kérdéssel is, hogy a kereskedelem digitalizációja által teremtett lehetőségek hogyan illeszthetők az in-store eszközökhöz.
\end{abstract}

\section{ALKALMAZOTT MÓDSZERTAN}

Tanulmányunk a témához kapcsolódó szakirodalmi források feldolgozásával, valamint kutatóintézetek jelentéseinek felhasználásával négy tényezőcsoportot vizsgál meg az in-store marketing eszközrendszeréből. Ezek a következők: a bolti atmoszféra, ezen belül is kiemelten a fizikai környezet, termék- és márkakínálat, promóciós ajánlatok és a digitális térhez való kapcsolódás innovatív megoldásai.

\section{LEGFONTOSABB EREDMÉNYEK}

Napjaink kereskedelmében a komplex vásárlói élmény az, amelyen keresztül egy vásárló lojalitása megszerezhető és hosszútávon megtartható. A fogyasztók magatartása megváltozott, az új fogyasztó új élményeket vár el, melyre az in-store marketing területén végbement innovációk is reflektálnak. A fizikai környezet, a boltok tereinek optimalizálása a vásárlások gyors és hatékony lebonyolítását teszi lehetővé, amely alapvető elvárássá vált. Stratégiai szerepet kapott az új trendekhez igazodó termék-, illetve kibővült kereskedelmi márkaválaszték, a jól kialakított in-store promóció, illetve a lojalitásprogramok eddiginél hatékonyabb működtetése. Új kihívást jelent a fogyasztók hibrid vásárlási magatartása (online és offline), melyhez a kereskedőknek is igazodniuk kell. Korunk digitális vívmányainak használata az áruk prezentálása, a kommunikáció vagy a fizetés terén alapvető versenytényezőnek fog számítani a kereskedelmi ágazatban is.

\section{GYAKORLATI JAVASLATOK}

Gyakorlati szempontból két területet érdemes kiemelni: az omnichannel használói magatartás, azaz az online és offline környezet egyidejű és ötvözött használata egyre elterjedtebb, így a lehetséges veszélyek ellenére ma már nem alternatíva, hogy a kereskedők ne fektessenek be az online értékesítésbe. Emellett másik kiemelhető terület a személyre szabottság, melynek kialakításához az in-store marketing számos eszközével hozzájárulhat, a személyre szóló szolgáltatásoktól kezdve a lojalitásprogramokig, vagy a digitalizáció adta szinte korlátlan lehetőségek kihasználásáig.

Kulcsszavak: kiskereskedelem, in-store marketing, vásárlói élmény, digitalizáció

Köszönetnyilvánitás: A publikáció elkészítését az EFOP-3.6.2-16-2017-00003 számú projekt támogatta. A projekt az Európai Unió támogatásával, az Európai Szociális Alap társfinanszírozásával valósult meg.

DOI: 10.15170/MM.2020.54.KSZ.II.03 


\section{BEVEZETÉS INTRODUCTION}

Számos különbség fedezhető fel napjaink és a késő 20. század fogyasztója között. A 21. század fogyasztójának sokkal több médium áll rendelkezésére a tájékozódáshoz, és lényegesen nagyobb kontrollal rendelkezik az üzenetek felett. Számtalan kereskedelmi lehetőség közül választhat, és éppen ezért kevésbé lojális egy csatornával szemben. A vállalatok számára alapvető azt felismerni, hogy egy „fogyasztó” szükségletei és motivációi gyökeresen megváltozhatnak, amint „vásárlóvá" válik (Christou 2017a).

Törőcsik (2017) szerint a vásárlási helyszín megválasztását két, egyidejüleg létező és müködő motiváció határozza meg: az egyik mozgatórugó a vásárló hatékonyságra, egyszerűsítésre való törekvése, a másik, hogy egyre fontosabbá válik a vásárlás élményként való megélése. A kényelem, a vásárlások gyors, hatékony lebonyolítása alapvetö igény, de ugyanilyen fontos szemponttá válik az átláthatóság, a kontroll lehetősége. Ezek a tényezők egyértelmúen utalnak arra a globális trendre, mely a magyar kereskedelemben is egyre inkább érezteti hatását, hogy a vásárlók egy teljes, komplett élményt várnak el egy-egy vásárlás során, ami így a verseny legmeghatározóbb tényezőjévé vált.

A szakirodalom széles körben foglalkozik az élmény multidimenzionális természetével és olyan benyomások összességeként írja le, amely a vásárló/fogyasztó termékkel, szolgáltatással való minden lehetséges interakciójának eredményeként jön létre (Walls et al. 2011). Kiemelhető Arnould et al. (2002) szintetizáló munkája, amelyben négy különböző interakciót különítettek el mint az élmény forrását: 1) anticipált fogyasztás (pl. információkeresés, vásárlás tervezése, költségvetés), 2 vásárlási élmény (pl. választás, fizetés, termékek választéka, atmoszféra), 3) fogyasztás élménye (pl. érzékszervi élmények, elégedettség/elégedetlenség), 4) emlékeztető fogyasztás (pl. múltbeli élményekre támaszkodás, nosztalgikus emlékek).

Az elvárt élmény tehát befolyásolja mind az üzletválasztási, mind a vásárlás helyén meghozott döntéseket, e kettő egybefonódott az egyre népszerübbé váló omnichannel (hibrid, online és offline) vásárlói magatartás elterjedésével. Számos, az üzletválasztást meghatározó tényező közül, mint a bolt atmoszférája, imidzse, belső kialakítása, a választék szélessége és mélysége stb., de akár az online vásárlás lehetősége mind részei annak a tapasztalatnak, melyek majd a komplex élményt formálják. Természetesen a fogyasztó involvált- sága, egy termék megvásárlásában való érzelmi, értelmi érintettsége erős befolyással bír a vásárlási döntési folyamat feladatként, vagy élményként való megélésére, mint ahogy a vásárlási döntés típusa is meghatározza azt (Törőcsik 2011). Figyelembe véve azonban a vásárlási élmény komplexitását, feltételezhetjük, hogy minden vásárlási döntéstípus (impulzus, rutin, korlátozott vagy kiterjesztett) esetén létezik olyan élményfaktor, mely ezeket a döntéseket támogatja.

A tanulmány célja kettős, egyrészt azokat az innovációkat tekinti át, melyek a vásárlói élményt létrehozó tényezők egyes elemeiben az elmúlt években megjelentek, illetve a globális tendenciákat figyelembe véve várhatóan meg fognak jelenni. Elsősorban az in-store marketing területére koncentrálunk, azonban látni kell, hogy a digitalizáció elterjedésével az offline és az online vásárlás közötti határok egyre inkább elmosódnak, melyre az alkalmazott in-store eszközöknek is reagálni kell. Ezért tanulmányunk második célkitűzéseként a digitális tér in-store marketinghez való illeszkedését vizsgáljuk meg.

\section{AZ ÉLMÉNYEK KIALAKÍTÁSA IN-STORE KÖRNYEZETBEN CREATING EXPERIENCES IN IN-STORE ENVIRONMENT}

Az élmény tehát sarkalatos pontja a vásárlói döntésnek, s mivel ennek a vásárlóhoz való eljuttatása fơként a vásárlás helyszínén történik, így ez az a pont, ahol az in-store marketingnek kulcsszerepe van. Az in-store marketing lényegét jól írja le az Instore Marketing Institution meghatározása: „A vásárló gondolkodásmódjának megismerése és ennek stratégiai felhasználása egy adott üzleti környezetben, a hatékony marketing- és értékesítési tevékenység megvalósítása érdekében" (Instore Marketing Institution in Silveira \& Marreiros 2014, 93). Gyenge (2010) szerint a vásárlás helyétől és idejétől, valamint a vásárló személyétől függetlenül a vásárlóközönséget körülvevő bolti környezet - hatását tekintve - soha nem lehet semleges, azaz már puszta létével is befolyásolja az oda belépőket. Ennek érdekében a kiskereskedelemnek úgy kell müködnie, mint egy színháznak: az áruházak és a termékek értékelése sokszor ettől a „teljesítménytől” függ. A résztvevők (pl. az eladószemélyzet, a jelenlévő vevők), a helyszín (pl. a bolt atmoszférája) illetve a „kellékek” (pl. áruházi displayek, POS, POP eszközök) mind befolyásolják az értékelést. Ezek a tényezők a vásárlás pillanatában befolyásoló további faktorokkal együtt, mint például az 
idő, az egyén hangulata, a megoldásra váró feladat drámai módon meg tudják határozni a vásárlás végeredményét (Baron et al. 2001).

A kereskedelem digitalizációjának legújabb korszakát az jelenti, hogy a fogyasztók okoseszközeikkel a kereskedelmi rendszerekhez tudnak kapcsolódni, amely nem csak a fogyasztók számára teszi a vásárlást élményszerüvé és testreszabottá, hanem a kereskedőket is olyan mennyiségü információval látja el a vásárlókról, amely új dimenziókat nyit számukra (Agárdi 2018).

A vásárlói élmény létrehozásában jelentős szerepet betöltő in-store tényezőrendszer minden elemével a tanulmány adta kereteken belül nem tudunk foglalkozni, így csak a legfontosabb innovációkat emeljük ki.

\section{BOLTI ATMOSZFÉRA, FIZIKAI KÖRNYEZET THE ATMOSPHERE OF THE STORE, PHYSICAL ENVIRONMENT}

Bár az online értékesítés egyre nagyobb részt hasít ki a kiskereskedelmi forgalomból, az értékesítés hagyományos módját, a fizikai boltokat sem szabad eltemetni. Tartós előnyük az online vásárlással szemben, hogy a vásárló szinte az összes érzékszervét használva válogathat a termékek között, és az impulzusvásárlás is nagyobb eséllyel következhet be. Az online vásárlás során a fogyasztókat ugyanis csupán audio és vizuális ingerek érik, nem kerülnek fizikai kontaktusba a termékkel (Flavián et al. 2017). Így azok a fogyasztók, akik számára fontosak az érzékszervi tapasztalások, az online helyett inkább az offline csatornát választják (Agárdi 2019, Flavián et al. 2017, Kemény \& Simon 2015, Rodrigues et al. 2017). Természetesen az érzékszervi érzékelésen túl más egyéb tényezők is a fizikai vásárlási környezet felé terelhetik a vásárlókat, melyek egy üzlet atmoszféráját alakítják ki.

Az üzlet atmoszférájának fogyasztói magatartásra gyakorolt hatását először Kotler (1973) vizsgálta, a kutatások manapság azonban leginkább a Mehrabian-Russell-modellre épülnek (Mehrabian \& Russell 1974), melyet először kiskereskedelmi környezetre Donovan és Rossiter (1982) alkalmazott. Bohl (2012) felfogása szerint az üzlet atmoszférájához a kiskereskedelmi környezet mindazon objektív fizikai faktorai tartoznak, amelyeket a vállalat képes kontrollálni annak érdekében, hogy fokozza vagy korlátozza a vásárlói és alkalmazotti cselekvéseket. Az atmoszférába számos elem tartozik, melyeket Turley és Milliman (2000) 5 kategóriába sorolt: külső változók (pl. az épület környéke, mérete, színe, bejárat), általános belső változók (pl. színek, fények, zene, illatok, hőmérséklet, árukészlet), elrendezés és dizájn változók (pl. az áru és a pénztárak elhelyezése, az osztályok elhelyezése, a sorban állás körülményei), vásárláshelyi és dekorációs változók (pl. POP eszközök, faldekoráció, árubemutatás, árak feltüntetése), humán változók (pl. alkalmazottak jellemzői, egyenruhák, vevők jellemzői).

Az eladótér, a bolti atmoszféra kialakításának meghatározó szerepe van az élmények „szállításában", ezért a kereskedők alapvető érdeke, hogy ebben is igazodjanak a fogyasztói elvárásokhoz. Az üzletek fizikai megjelenése, az áruk prezentálása területéről két példa:

- A magyar fogyasztók üzletválasztási szokásait illetően a diszkontok térnyerése figyelhető meg, mivel ebben az üzlettípusban gyorsan és kényelmesen le lehet bonyolítani a bevásárlásokat (Kisari 2016). Így a fogyasztói elvárásokhoz igazodva a kiskereskedelmi láncok egyre zsugorodó területü üzletekben bonyolítják le forgalmukat. Az eladóterek csökkenése miatt a helykihasználásnak egyre hatékonyabbnak kell lenni, melynek részeként zajlik több áruházban az eladótér optimalizációja is. Ennek példájaként a magyarországi Tesco a tízezer négyzetméternél nagyobb áruházaiban megszünteti a rosszul teljesítő termékek (pl. müszaki cikkek) értékesítését, kínálatát a minőség irányába koncentrálja, a megszünt területeket pedig szolgáltatóknak adják bérbe. Tulajdonképpen a hipermarketek - a vásárlói elvárásokhoz igazodva - egyfajta bevásárlóközpontokká alakulnak át (Portfolio 2019).

- A vásárlók boltválasztásra vonatkozó döntési szempontjai között elökelő helyet foglal el, hogy a keresett áru mindig rendelkezésre álljon (Christou 2017a). Ha egy vásárló nem találja a terméket, helyettesítő terméket vásárol, vagy egy másik üzletet keres (Pólya 2019). Globális szinten átlagosan a termékek több mint 8\%-a nincs készleten, és a fogyasztók az esetek felében tízből egy terméket nem tudnak beszerezni egy vásárlás alkalmával. Ez az arány a kereskedelem fejlettségétől függöen országonként változik, de még a vezető piacokon is 1,5-2\%-ra tehető a kifogyott termékek aránya (Nielsen 2018). Az online kereskedelem leegyszerüsítette az árak és a kínálatok összehasonlítását, 
így a vevő könnyen választ másik márkát, vagy akár üzletet is, $\mathrm{s}$ ennek eredményeként veszíthet el a kereskedő egy vevőt.

\section{TERMÉK- ÉS MÁRKAVÁLASZTÉK PRODUCT AND BRAND RANGE}

A kereskedelemnek az innovációk támogatásában kiemelt szerepe van, hiszen a versenytársakhoz képest megkülönböztető termékválaszték esetükben is stratégiai jelentőséggel bír. Az innováció trendjei világosan láthatók: egyre több kereskedő vállalja fel azt a szerepet, hogy jutalmakkal, promóciókkal, márkatámogatással egy egészségesebb életstílus felé terelje a fogyasztókat, melyre a magyarok is egyre nyitottabbak.

Kijelenthetö, hogy az új trendekre (egészségtudatos, kényelmi) reflektáló, magas hozzáadott értékkel rendelkezö márkák növekvö eladási potenciált jelentenek. Egyre többen engedhetnek meg maguknak prémium termékeket. Egy Nielsen felmérés szerint 2016-ban a megkérdezett magyar fogyasztók 43\%-a nyilatkozott úgy, hogy egy évvel azelőtt kevésbé vehette meg ezeket a minőségi termékeket. Ennek egyértelmü bizonyítéka, hogy a top 10 termékkategóriában megnőtt a kereslet a prémium termékek iránt. A prémiumizáció tehát a növekedési potenciál egyik fontos eleme (Christou 2017a).

A kereskedelmi láncok termék- és márkastruktúrájának további meghatározó trendje, hogy a kereskedelmi márkák egyre inkább reflektorfénybe kerülnek. A kereskedelmi vállalatok jelentôs mértékben kibövitették saját márkaportfóliójukat. A privát címkék már nem az olcsó és kevésbé vonzó alternatívát jelentik (Cuneo et al. 2012), differenciáltságuk, pozicionálásuk révén eltérő szegmenseket képesek megcélozni, számos saját márka márkaszemélyisége felveszi a versenyt a termelői márkákéval (Agárdi 2018, Thompson 2019). Balló (2014) a magyar fogyasztók kereskedelmi márkákkal kapcsolatos attitúdjére vonatkozó kutatásában arra jutott, hogy a várttal ellentétben, a magas jövedelműek is gyakran választják ezeket a márkákat, mely valószínúleg a kereskedelmi márkák minőségjavulásának, újra-pozicionálásának köszönhető. A kedvező tapasztalat szintén összefügg a választással, de a szerző arra is rámutatott, hogy adott termékkategóriában való érintettség meghatározza a saját márkás termékek vásárlását. Magyarországon 2018-ban a megvásárolt termékek harmada kereskedelmi márkás termék volt. A PLMA (Saját Márkák Marketing Szövetsége) 2018-as felmérése szerint a kereskedelmi márkák 34\%-os részese- déssel rendelkeznek (ezen belül az élelmiszer-kategóriában 29\%-kal), mely részarány várhatóan tovább emelkedik. Ennek oka a kereskedelmi márkák forgalmazásában élenjáró diszkont csatornák forgalmának olyan mértékủ növekedése, mellyel átvették az első helyet a tartósan vezető hipermarketektől. Európa országairól általánosan is elmondható, hogy rendkívül népszerủek a saját márkák, részarányuk eléri a 30\%-ot, de például a „kemény diszkontok" hazájában, Németországban 45\%-os a részesedésük (Trade magazin 2019).

\section{ALKALMAZOTT PROMÓCIÓS AJÁNLATOK APPLIED IN-STORE PROMOTION}

A kereskedelmi alternatívák kiszélesedése a vásárlók igényeinek és elvárásainak a növekedését eredményezi, egyben potenciálisan csökkenti lojalitásukat. Ennek eredményeként sokszor napi szinten hoznak döntéseket a vásárlásaikról az egyéni tapasztalatok, a termék elérhetősége, a kényelem, az érték, az ár és egyéb tényezők, azaz a korábbi vásárlási élmények alapján. Így a kiskereskedőknek új kihívásokkal kell szembenézniük és új módszereket kell találniuk a fogyasztók vonzására és a magas szintü ügyfélhüség ösztönzésére (Kiran et al. 2012).

A vállalatok milliárdokat költenek promotálásra, így egyre inkább keresik azokat a megoldásokat, melyek a legköltséghatékonyabbak. Juhász (2019) rámutatott az in-store promóció jelentőségére a dunnhumby piacelemző cég által lebonyolított kutatás adatait ismertetve: a megkérdezett magyar fogyasztók $76 \%$-a nyilatkozott úgy, hogy a polcok elött dönti el, hogy mit fog vásárolni, a megkérdezettek $80 \%$-a pedig úgy gondolta, hogy legutóbbi vásárlása során befolyásolták őt az eladás helyén alkalmazott eszközök. Egy bolt forgalmát átlagosan 21\%-kal lehet növelni átgondolt in-store ösztönzéssel, figyelembe véve, hogy az eladótérben alkalmazott eszközök hatása elnyújtott, azaz befolyásolják a promóció utáni időszakot is.

A kereskedők elöszeretettel alkalmaznak promóciókat (akciók, multipackok, nyereményjátékok, lojalitásprogramok stb.) a fogyasztás bővítésére, melyre a magyar vásárlók kifejezetten fogékonyak. 2016-ban 100 magyar vásárlóból 74 nyilatkozott úgy, hogy kifejezetten érdeklik a promóciók. Bár a legkedveltebbnek az árengedmények számítanak, de a túl gyakori, vagy nagy mértékủ árcsökkentések nem feltétlenül vezetnek nagyobb eladott mennyiséghez (Christou 2017a). 
A vevők lojalitásprogramba való bevonása a hosszú távú elköteleződés leghatékonyabb eszközének számít, melynek egyik legnagyobb hozadéka, hogy a kereskedők jelentős mennyiségü adattal rendelkeznek a vásárlókról, amely a személyre szabott ajánlatok kialakítását teszi lehetővé (Agárdi 2018). Ez annál is sürgetőbb, mint az EY Retail Loyalty kutatása alapján kiderült, hogy a kiskereskedők és szolgáltatók mindössze $5 \%$-a szerint lojálisak hozzá a fogyasztói. Az elkötelezettség kialakítására alkalmazott programokat nem érzik hatékonynak, sőt $80 \%$-uk szerint akár az üzlet nyereségességét is ronthatja. Mindez alátámasztja Grewal et al. (2011) véleményét, mely szerint folyamatosan szükséges vizsgálni a személyre szóló, célzott ajánlatok nyereségességét. Az EY Retail Loyalty kutatásának eredményei azt mutatják, hogy a megkérdezett cégvezetők több mint harmada már gyüjti az adatokat, sőt 30\%-uk már arra is képes, hogy ezek alapján személyre szabott ajánlatokat dolgozzon ki (Termékmix 2018a). Az ügyfelekröl összegyüjtött adatok hozzásegítik a vállalatot, hogy az egyéni fogyasztó szemszögéből szemlélje a költségeket és hasznokat (Grewal et al. 2011).

\section{KAPCSOLÓDÁS A DIGITÁLIS TÉRHEZ CONNECTION TO THE DIGITAL SPACE}

\section{Omnichannel (hibrid) és multichannel vásárlói magatartás \\ Omnichannel (hybrid) and multichannel costumer behaviour}

A világ jelenleg a kapcsolatok robbanásszerü változásának lehet szemtanúja, és bár az IoT világa megváltoztatta a piaci erőviszonyokat, a versenyelőnyök forrásait, a szabályokat valójában a vásárlók határozzák meg azáltal, hogy minden érintkezési ponton egyszerü, gördülékeny és személyre szabott élményeket igényelnek (Sikos és tsai 2019).

A megváltozott fogyasztói magatartás következményeként kialakultak az ún. omnichannel (hibrid), illetve multichannel csatornahasználati szokások. A digitális technológiákkal kapcsolatos innovációk (pl. okostelefon applikációk) segítségével a vállalkozások egyre hatékonyabban képesek támogatni az ügyfelek döntéshozatalát és közvetíteni a vásárlás során szerzett tapasztalataikat az online és offline csatornák között. A fogyasztók showrooming (böngészés a boltban, vásárlás online), illetve webrooming magatartása (böngé- szés online, vásárlás a boltban) teljesen általánossá vált, melyhez a kereskedőknek, gyártóknak is igazodniuk kellett (Margetis et al. 2019). Jing (2018) kutatása bizonyítja, hogy a vállalkozások webrooming és showrooming stratégiája összefügghet, hiszen ezek képesek egymás hatásait felerősíteni és ezzel minél több fogyasztót bevonni a részvételbe, ami magasabb nyereséget eredményez. Kang (2018) szerint az omnichannel ügyfél showrooming és webrooming magatartása pozitívan befolyásolja a felhasználók által létrehozott tartalmakat a közösségi média felületeken. Flavián et al. (2019) a webrooming magatartás előnyeként jelölte meg, hogy a fogyasztók a vásárlási döntésüket hatékonyan képesek megalapozni a bolti látogatást megelőző online kereséssel és így viszonylag gyorsan hozzá tudnak jutni az elöre kinézett termékhez.

Az omnichannel stratégia egyre inkább követelménnyé válik. Egy tanulmány szerint például azok a vállalatok, amelyek omnichannel ügyfélelkötelezettségi stratégiával rendelkeznek, átlagosan ügyfeleik $89 \%$-át tudják megtartani, szemben a gyenge omnichannel stratégiával rendelkezők 33\%-os arányával. A tanulmány további meggyőző eredménye, hogy a hibrid csatornaválasztási szokásokat mutató vásárlók élettartamértéke 30\%-kal magasabb, mint azoké, akik csupán egy csatornát használnak (Saleh 2016).

Az omnichannel stratégia alkalmazhatóságát a Marshoek tanácsadó vállalat tanulmánya is alátámasztja. Számításaik szerint az online értékesítésbe beszálló kiskereskedők ugyan kevesebb nyereséget termelnek, mintha csak offline értékesítenének (a kiszállításhoz kapcsolódó költségek, valamint amiatt, hogy az online rendelö fogyasztók kevesebbet költenek), mégsem tanácsolják, hogy a kereskedők ne invesztáljanak az online csatornákba, hiszen az ma már elengedhetetlen (Termékmix 2018b).

\section{Új in-store technológiák New in-store technologies}

A kényelem az egyik leginkább elvárt élményfaktor, amelyben kiemelkedő szerepe van a bolti (in-store és digitális) technológiáknak. A digitális technológiák alkalmazásával növelhető a boltban eltöltött idő, elősegíti a fogyasztó bevonódását és ezáltal nő a fogyasztói lojalitás. Napjaink kompetitív kereskedelmi környezetében e technológiák révén mind a gyártók, mind a kereskedők hozzáadott értéket hozhatnak létre. A számtalan opció közül az európai országokban az olyan mobiltechnológiák a legelterjedtebbek, mint a mobilkupon, egyedi kereskedelmi alkalmazások, illetve az ingyenes wifi. 
A Nielsen 2017-es felmérése szerint Magyarországon a mobilkuponok még nem annyira elterjedtek, mindössze a megkérdezettek $16 \%$-a élt már ezzel a lehetőséggel. A hüségprogramos applikációk aktív felhasználójának $13 \%$ vallotta magát, míg a boltok ingyenes wifi-hálózata segítségével mindössze a megkérdezettek tizede próbált további információkat gyüjteni (Christou 2017b).

A SoLoMo (social-local-mobile) marketing egy további lehetőség, amelynek során az okostelefon segítségével az egyének a fizikai boltban tapasztaltakat megosztják a közösségi média platformjaikon. Így akár valósidejü és a helyadatokkal kiegészített keresések és csevegések bonyolíthatók le, amelyek döntéstámogató funkcióval bírnak a vásárlások során (Rouse 2013).

A technológiai fejlödés megjelenik a kommunikációs tevékenységben is. Az üzleten belüli kommunikációt is forradalmasítják az olyan digitális technológiák, mint a virtuális eladók, okostükrök stb., de az eladószemélyzettel való kapcsolat szimulálása online környezetben is megvalósítható, például chatbotokon keresztül (Agárdi 2018). Az intelligens bevásárlókocsik, robotok segítenek a navigálásban, információk, akciók keresésében, de akár további termékeket is ajánlhatnak.

Az önkiszolgáló pénztárak, kézi szkennerek egyre elterjedtebbek, a magyar fogyasztók 16\%-a próbálkozott már az önkiszolgáló fizetési móddal. A termék nyomon követhetőségét biztosító QR kódok használata egyelőre nem túl népszerü, a magyar válaszadók harmada egyértelműen elutasította ezt a lehetóséget (Christou 2017b). Ezt Füzesi és tsai (2018) magyar mintán végzett vizsgálata is megerősíti, hiszen a válaszadók mindössze 8\%-a nézi ezeket a kódokat.

A rendelkezésre álló pénz egy olyan korlát, melynek lebontása a kereskedők alapvető érdeke, s melynek érdekében számos új fizetési alternatíva áll rendelkezésre. A különbözö készpénzmentes fizetési lehetöségek (érintés nélküli bankkártyák, mobilfizetés) egyre elterjedtebbek, ezek a megoldások már nem szokatlanok a magyar áruházakban sem.

\section{ÖSSZEGZÉS SUMMARY}

Tanulmányunk az in-store marketing területének néhány olyan innovációját tekintette át, melyeknek napjainkban, illetve a közeljövőben a vásárlói élmény megteremtésében meghatározó szerepe lehet. Vizsgálatunkban kiemelt szerepet kapott a digitális térhez való csatlakozás jelentősége.
$\mathrm{Az}$ áttekintett in-store innovációk mindegyike szerves részét képezi a folyamatosan változó elvárt élmény megteremtéséhez való alkalmazkodási képességnek. Egyes üzlethálózatok kiváló példát nyújtanak arra, hogyan lehet a bolti atmoszféra fizikai tényezőinek az alakításával reagálni a fogyasztók igényeire. Az eladóterek optimalizációjával, szükítésével, a szolgáltató szerep erősítésével a két legjellemzőbb vásárlói motivációra válaszolnak - a vásárlás legyen élményeket biztosító és hatékony.

A minőségi, trendkövető termékek a növekedési potenciál egyik fontos elemévé váltak, így az innovációk támogatásában a kereskedelemnek továbbra is kulcs szerepet kell vállalnia. A márkaválaszték egyre jelentősebb részét képezik a diverzifikált, jól pozícionált kereskedelmi márkák is. Mivel részarányuk várhatóan növekedni fog, így a vásárlói igények pontosításában még jelentős kutatási potenciál lehet.

A magyar vásárlók számára a promóciók az élmény egyik legfontosabb forrását jelentik. Tanulmányunkban rámutattunk, hogy jelentős részben a polcok elött dől el, hogy mi kerül a kosarakba, így soha nem volt ilyen fontos, hogy ne csak taktikai, hanem stratégiai szinten gondolkodjanak a vállalatok a promóciókról. Igaz ez a kereskedők által előszeretettel alkalmazott lojalitásprogramokra is, melyek hatékonyságát a bővülő adatbázisokra támaszkodó személyre szabott ajánlatokkal lehetne növelni. Ugyanakkor mind a promóciók, mind a célzott ajánlatok költséghatékonysága folyamatos felülvizsgálatot és kutatást igényel.

A fogyasztók csatornahasználati szokásaiban az omnichannel (online és offline egymást kiegészítve) vásárlói magatartás egyre jellemzőbbé válik, melyhez a kereskedőknek is igazodniuk kell. Ugyan számolni lehet azzal a veszéllyel, melyre egyes tanulmányok utalnak, hogy az online értékesítésbe való befektetés után kevesebb nyereséget termelnek, mintha csak offline értékesítenének, ám az online csatornák mellőzése ma már nem alternatíva. A digitális technológiák egyre szélesebb körú alkalmazása elengedhetetlen in-store környezetben is, melyekkel szemben a fogyasztók egyre nyitottabbak. Bár szakértők szerint a hagyományos és digitális technológiák összehangolásáig még éveket kell várni, hosszabb távon várhatóan ezek az előnyök alapvető elvárásként jelennek majd meg, melyre fel kell készülni a kereskedőknek is.

Tanulmányunk csupán néhány szeletét érintette az in-store marketing gazdag eszköztárának, de így is kirajzolódott számos olyan terület, mint a kereskedelmimárka-stratégiák, a promóciók és személyre szabott ajánlatok nyereségességének határai, vagy az omnichannel-stratégia hatékonysága, mely számos izgalmas kutatás témájául szolgálhat. 


\section{HIVATKOZÁSOK REFERENCES}

Agárdi I. (2018), „Kereskedelem és trendjei”, MTA vitaindító anyag

Agárdi I. (2019), „A tapintás iránti preferencia mediáló hatása a fogyasztó neme, a termék típusa és a csatornaválasztás kapcsolatában", Vezetéstudomány, 50(1), 70-79 DOI: 10.14267/ VEZTUD.2019.01.07

Arnould, E. J. and Price, L. L. (1993), "River Magic: Extraordinary Experience and the Extended Service Encounter", Journal of Consumer Research, 20(1), 24-45 DOI: 10.1086/209331

Balló, Z. (2014), „Empirikus eredmények a fogyasztók kereskedelmi márkákkal kapcsolatos attitüdjéről a napi fogyasztási cikkek piacán", Marketing \& Menedzsment, 48(1), 25-36

Baron, S., Harris, K. and Harris, R. (2001), "Retail Theater: The "Intended Effect" of the Performance", Journal of Service Research, 4(2), 102117 DOI: $10.1177 / 109467050142003$

Bohl, P. (2012), "The Effects of Store Atmosphere on Shopping Behaviour - A Literature Review", Corvinus Marketing Studies, No. 1., Budapesti Corvinus Egyetem, Budapest

Christou, A. (2017a), „A promó mindent visz?”, https://www.nielsen.com/hu/hu/insights/article/2017/promo-above-all/ (Utolsó letöltés: 2019. 09.02.)

Christou, A. (2017b), Technológia a bolti eladótérben, https://www.nielsen.com/hu/hu/insights/ article/2017/instore-technology/_ (Utolsó letöltés: 2019. 09.02.)

Cuneo, A., Lopez, P. and Yague, M. (2012), "Private Label Brands: Measuring Equity Across Consumer Segments", Journal of Product \& Brand Management, 21(6), 428-438 DOI: 10.1108/10610421211264919

Donovan, R. J. and Rossiter, J. R. (1982), "Store Atmosphere: An Environmental Psychology Approach", Journal of Retailing, 58(1), 34-57

Flavián, C., Gurrea, R. and Orús, C. (2017), “The Influence of Online Product Presentation Videos on Persuasion and Purchase Channel Preference: The Role of Imagery Fluency and Need for Touch", Telematics and Informatics, 34(8), 1544-1556 DOI: 10.1016/j.tele.2017.07.002

Füzesi I., Gyarmati Á., Lengyel P., Felföldi J. (2018), „Élelmiszer-jelölések hatása a fogyasztói döntésekre - különös tekintettel a nyomon követésre", Gazdálkodás, 62(5), 444458.

Grewal, D., Ailawadi, K. L., Gauri, D., Hall, K.,
Kopalle, P. and Robertson, J. R. (2011), "Innovations in Retail Pricing and Promotions", Journal of Retailing, 87, S43-S52 DOI: 10.1016/j. jretai.2011.04.008

Gyenge B. (2010), „A fogyasztói boltválasztás magyarázatának modellezési lehetőségei II.", Marketing \& Menedzsment, 44(4), 11-24

Jing, B. (2018), "Showrooming and Webrooming: Information Externalities Between Online and Offline Sellers", Marketing Science, 37(3), 469483 DOI: $10.1287 / \mathrm{mksc} .2018 .1084$

Juhász A. (2019), „Megtérülés a trade marketingben - In-store kampány a növekedésért", https:// trademagazin.hu/hu/megterules-a-trade-marketingben-in-store-kampany-a-novekedesert/ (Utolsó letöltés: 2019.09.02.)

Kang, J-Y. M. (2018), "Showrooming, Webrooming, and User-Generated Content Creation in the Omnichannel Era", Journal of Internet Commerce, 17(2), 145-169 DOI: 10.1080/15332861.2018.1433907

Kemény I., Simon J. (2015), „Termékek és szolgáltatások vásárlása online - vajon mások az elvárások?", Vezetéstudomány, 46(7), 28-40

Kiran, V., Majumdar, M. and Kishore, K. (2012), "Innovation in In-Store Promotions: Effects on Consumer Purchase Decision", European Journal of Business and Management, 4(9), 36-44

Kisari É. (2016), „Kategóriák nagy és kis boltokban", https://www.nielsen.com/hu/hu/insights/ article/2016/global-report-about-big-and-smallformats/ (Utolsó letöltés: 2019.09.09.)

Kotler, P. (1973), "Atmospherics as a Marketing Tool", Journal of Retailing, 49(4) 48-64

Margetis, G., Ntoa, S. and Stephanidis, C. (2019), "Smart Omni-Channel Consumer Engagement in Malls", HCI International 2019 - Posters, 89-96 DOI: 10.1007/978-3-030-23525-3 12

Mehrabian, A. and Russell, J. A. (1974), An Approach to Environmental Psychology, Cambridge, MA: MIT Press

Nielsen (2018), „Készleten és olcsón”, https:// www.nielsen.com/hu/hu/insights/article/2018/ in-stock-and-inexpensive/ (Utolsó letöltés: 2019.09.03.)

Pólya, É. (2019), “The Interrelationship Between the Factors Influencing Retail Selection Behavior and FMCG Market Network", Economica, 10(Új évf. 2), 77-62

Portfolio (2019), „Hatalmas változások jönnek a Tesco magyar hipermarketeiben", https:// www.portfolio.hu/vallalatok/hatalmas-valtozasok-jonnek-a-tesco-magyar-hipermarketeiben.332097.html (Utolsó letöltés: 2019.09.01.)

Rodrigues, T., Silva, S. C. and Duarte, P. A. O. 
(2017), "The Value of Textual Haptic Information in Online Clothing Shopping", Journal of Fashion Marketing and Management: An International Journal, 21(1), 88-102 DOI: 10.1108/ JFMM-02-2016-0018

Rouse, M. (2013), SoLoMo, https://searchmobilecomputing.techtarget.com/definition/SoLoMo-social-local-and-mobile (Utolsó letöltés: 2020.04.05.)

Saleh, K. (2016), The State of Omnichannel Shopping - Statistics and Trends. INVESP, https:// www.invespcro.com/blog/state-of-omnichannel-shopping/ (Utolsó letöltés: 2019.09.01.)

Sikos, T. T., Kozák, T., Kovács, A. (2019), "New Retail Models in Online And Offline Space", Deturope, 11(3), 9-28

Silveira, P. D. and Marreiros, C. (2014), "Shopper Marketing: A Literature Review", International Review of Management and Marketing, 4(1), 90-97

Termékmix (2018a), Lejárt a hagyományos hüségprogramok ideje, http://termekmix.hu/ kereskedelem/kutatas/577-lejart-a-hagyomanyos-husegprogramok-ideje. (Utolsó letöltés: 2019.08.20.)

Termékmix (2018b), Többcsatornás kereskedelem - Költséges lehet az online kereskedelem a szupermarketeknek, http://termekmix.hu/ kereskedelem/kutatas/702-tobbcsatornas-kereskedelem-koltseges-lehet-az-online-kereskedelem-a-szupermarketeknek (Utolsó letöltés: 2019.09.04.)
Thompson, T. (2019), 4 Retail Trends Refining the In-Store Experience in 2019, RRD Marketing Solution, https://blog.rrdonnelley.com/retailtrends-refining-the-in-store-experience-2019/ (Utolsó letöltés: 2019.08.28.)

Törőcsik M. (2011), Fogyasztói magatartás - Insight, trendek, vásárlók, Budapest: Akadémiai, DOI: 10.1556/9789630597371

Törőcsik M. (2017), „A kereskedelem új vonásai", Trendtanulmány. Dr. Törőcsik Marketing Inspiráció Fogyasztói Magatartás Kutató Intézet, Trendinspiráció Mühely

Trade magazin (2019), Saját márkák rangsora és rekordjai, https://trademagazin.hu/hu/ sajat-markak-rangsora-es-rekordjai/ (Utolsó letöltés: 2019.08.28.)

Turley, L. W. and Milliman, R. E. (2000), "Atmospheric Effects on Shopping Behavior: A Review of the Experimental Evidence", Journal of Business Research, 49 193-211 DOI: 10.1016/ S0148-2963(99)00010-7

Walls, A., Okumus, F., Wang, Y. and Kwun, D. J. W. (2011), "Understanding the Consumer Experience: An Exploratory Study of Luxury Hotels", Journal of Hospitality Marketing \& Management, 20(2), 166-197 DOI: $10.1080 / 19368623.2011 .536074$ 
Kontor Enikő $\mathrm{PhD}$, adjunktus kontor.eniko@econ.unideb.hu

Kiss Marietta PhD, adjunktus kiss.marietta@econ.unideb.hu

Fehér András $\mathrm{PhD}$, adjunktus feher.andras@econ.unideb.hu

Debreceni Egyetem Gazdaságtudományi Kar

\section{The role of in-store marketing innovations in creating a customer experience and its connections to the digital space}

\section{THE AIMS OF THE PAPER}

The study reviews the innovations and trends that determine the opportunities and challenges of in-store marketing today and in the near future and at the same time play an important role in creating a customer experience. We also focus on the question of how the opportunities created by the digitization of commerce can be fitted to in-store tools.

\section{METHODOLOGY}

Our study examines four groups of factors from the in-store marketing tools by processing the literature related to the topic and using the reports of research institutes. These are: the store atmosphere, especially the physical environment, product and brand offerings, promotional offers, and innovative solutions for connecting to the digital space.

\section{MOST IMPORTANT RESULTS}

In today's commerce, the complex customer experience is through which the loyalty of a customer can be gained and maintained in the long run. Consumer behaviour has changed, the new consumer expects new experiences, which is also reflected by the innovations that have taken place in the field of in-store marketing. The optimization of the physical environment and the space of the shops enables the fast and efficient execution of purchases, which has become a basic requirement. A strategic role was given to the product range and the expanded store brand range in line with the new trends, the well-designed in-store promotion, and the operation of loyalty programs more efficient than before. A new challenge is the hybrid purchasing behaviour of consumers (online and offline) to which traders and manufacturers must also adapt. The use of the digital advances of our time in the presentation of goods, communication or payment will also be a fundamental competitive factor in the commercial sector.

\section{RECOMMENDATIONS}

From a practical point of view, two areas are worth highlighting: Omnichannel user behaviour, i.e., simultaneous and combined usage of online and offline environments, is increasingly popular, therefore in spite of the possible dangers, today it is not a viable option for merchants not to invest in online commerce. Beside this, another area to be highlighted is customization, to which in-store marketing may contribute with its several tools, from personalized services through loyalty programs, to taking advantage of the almost limitless opportunities of digitization.

Keywords: retailing, in-store marketing, consumer experience, digitization

Acknowledgement: The publication is supported by the EFOP-3.6.2-16-2017-00003 project. The project is co-financed by the European Union and the European Social Fund. 